ELORE (ISSN 1456-3010), vol. 15 - 1/2008.

Julkaisija: Suomen Kansantietouden Tutkijain Seura ry.

[http://www.elore.fi/arkisto/1_08/lau1_08.pdf]

\title{
KIRJA-ARVIO:
}

\section{ESTETIIKAN JÄLJILLÄ, MAISEMAN ÄÄRELLÄ}

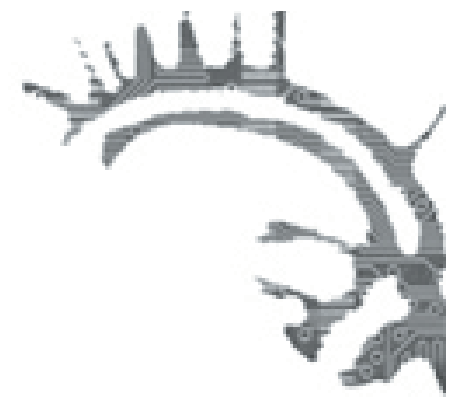

Sepänmaa, Yrjö \& Heikkilä-Palo, Liisa \& Kaukio, Virpi (toim.) 2007: Maiseman kanssa kasvokkain. Helsinki: Maahenki Oy. 328 sivua.

\section{Kirsi Laurén}

Miten elävästi runoilija kykeneekään maalaamaan mieleemme muutamalla lauseella maiseman ja sen tunnelman, kuten Eeva-Liisa Manner tekee runossaan "Kuolleet vedet" (1977):

Tie on himmeä, kirkas

himmeä, keltainen

ja rannalla vaeltavat

kahlaajan sumuiset äänet.

Ne ovat lauseita.

Ilta kokee verkkojaan.

Metsässä kehrääjän ääni:

kutsu tai valitus.

Jokipuun tuoksu, ja kaislan

ohut kaanon.

Maisema sisältää kaikin aistein havaittavia ominaisuuksia, joiden inhimilliseen ilmentämiseen tarjoavat ehkä parhaimmat apuvälineet mielikuviin pohjaavaa ja metaforista ilmaisua käyttävät taidemuodot. Maiseman tieteellinen haltuunotto, käsitteellistäminen ja määritteleminen, vaatii puolestaan runsaasti sanoja, selittämistä ja perusteluja. Maiseman ja erityisesti sen esteettisen tarkastelun äärellä ollaan monialaisesti tieteen ja taiteen keinoin ympäristöestetiikan kirjasarjan viimeisimmässä artikkelikokoelmassa 


\section{ESTETIIKAN JäLJILÄ, MAISEMAN ÄÄRELLÄ}

Maiseman kanssa kasvokkain. Artikkelikokoelma pohjaa ensimmäiseen, vuonna 1994 Kolin kansallismaisemissa pidettyyn ympäristöestetiikan kansainväliseen konferenssiin "Kohtauspaikkana maisema". Aikaa konferenssista kirjan ilmestymiseen keväällä 2007 on siis vierähtänyt noin 13 vuotta. Kirjan ovat tuttuun tapaan toimittaneet konferenssien sarjaa luotsaava professori Yrjö Sepänmaa, Maaseudun Sivistysliiton kulttuuritoimenjohtaja Liisa Heikkilä-Palo sekä tutkija Virpi Kaukio.

\section{MAISEMAN LÄHESTYMINEN JA ESITTÄMINEN}

Kirjasarjan aiemmin ilmestyneissä teoksissa tarkastellaan rajatummin erilaisia ympäristöjä: suota (1999), vettä (2002), metsää (2003) ja peltoa (2005). Tämän alun perin kansainvälisen ympäristöestetiikan sarjan johdannoksi suunnitellun kirjan ja sitä edeltäneen konferenssin perspektiivi on laaja-alaisemmin maisema. Siksi myös kirjoitukset laajenevat moniin eri suuntiin ja lähtökohtiin kiinnittymättä yhteisesti mihinkään tiettyyn maisematyyppiin tai -elementtiin. Maiseman käsitteellä on runsaasti tarttumapintaa ja selitysvoimaa, niinpä sitä myös käsitellään kirjan artikkeleissa useiden erilaisten esimerkkikohteiden, kuten Kolin, kansallisten maisemakuvastojen ja puutarhojen yhteydessä. Yhteisenä teemana artikkeleissa voi kautta linjan nähdä ihmislähtöisyyden, ihmisen ja maiseman suhteen pohdinnan, jonka keskeisenä ulottuvuutena ovat suurelta osin esteettiset aspektit. Koko ympäristöestetiikan kirjasarjaa ajatellen Maiseman kanssa kasvokkain näyttäytyy tuoreimmasta julkaisuajankohdastaan huolimatta johdantoteoksena, ja sellaisena suosittelisin sitä myös luettavan. Maisemakäsitteen ja siihen nivoutuvien tarkastelutapojen avaajana se luo pohjaa jo aiemmin ilmestyneille teoksille.

Artikkelit jakautuvat alun jälkeen kuuden eri otsakkeen alle: "Maiseman kerrokset", "Maiseman arvot ja niiden ymmärtäminen", "Maiseman kohtaaminen", "Maisema kansakunnan sydämessä", "Maiseman sääntelyn keinot" ja "Maisema ja taide". Kansainvälisten kirjoittajien joukossa on useita kirjasarjassa aiemmin tutuksi tulleita tiede- ja taidemaailman edustajia: Ronald W. Hepburn, Holmes Rolston III, Allen Carlson, Yuriko Saito, Cheryl Foster, Arnold Berleant, Barbara Dandrisser, Maria Miller ja Maria Golaszewska. Ensimmäistä kertaa ovat mukana korealainen Kim Moon Hwan ja kanadalainen Arlene J. Kwasniak. Kirjasarjan puitteissa aiemmin esiintyneistä suomalaisista kirjoittajista ovat jälleen mukana Pauline von Bonsdorff, Hannes Sihvo, Pertti Rannikko ja Lauri Anttila. Muun muassa maisema- ja ympäristöteeman myötä muissa yhteyksissä varsin tunnettuja kirjoittajia ovat Leena Vilkka, Pauli Tapani Karjalainen, Maunu Häyrynen ja Matti K. Mäkinen.

Kuvitus on jälleen kirjasarjan linjalle uskollisesti upea. Kuvat saavat tarttumaan kirjaan ja ne tekevät siitä esteettisen elämyksen. Maisemaan melkein pääsee sisälle - ainakin pienellä mielikuva-avustuksella. Useissa kuvissa on läsnä ihminen, luontoa ja maisemaa katsellen, siinä ollen ja eläen. Kuvista välittyvä ilmapiiri on kiireetön ja rauhoittava, se houkuttelee viivähtämään. Työn- ja toiminnantäyteiset maisemat näyttäytyvät jossain määrin kirjan artikkeleissa, mutta kuvien osalta ne on suljettu teoksen 


\section{KiRSI LAURÉN}

ulkopuolelle. Ainoastaan pienenä muistutuksena toiminnan taustana esittäytyvästä maisemasta ovat kirjan johdantosivuilta löytyvät pienikokoiset kaskenpoltto- ja pelitilannekuvat. Valokuvaajina ovat sekä artikkelien kirjoittajat että nykyvalokuvataiteilijat, joiden kuvia oli esillä myös kesällä 2007 "Maiseman kanssa kasvokkain" -valokuvanäyttelyssä Juuassa, Suomen Kivikeskuksessa. Käsillä oleva samanniminen kirja julkaistiin näyttelyn avajaisissa. Näyttelyn kuraattorina toimi myös koko tähänastisen estetiikan kirjasarjan kuvatoimittaja Ritva Kovalainen. Näyttelyn, kuten myös kirjan, kustantaja on Maaseudun Sivistysliiton kustantamo Maahenki Oy.

\section{TUORETTA JA MUISTISTA LÖYTYVÄÄ}

Henkilökohtaisesti kirjasta jäivät kirkkaimpina ja tuoreimpina teksteinä mieleeni Kiinan ja Japanin itämaista perinnettä ja luontokäsityksiä tarkastelevat Kim Moon Hwanin ja Barbara Sandrissenin artikkelit. Kiinnostava näkökulma nousee esiin myös Maria Golaszewskajan empiirisiin aineistoihin pohjautuvassa artikkelissa, jossa hän käsittelee toistaiseksi varsin vähän tutkittua lasten esteettistä herkkyyttä ja luonnon kauneuden havainnointia. Artikkelin mieleenpainuvuutta edesauttoivat myös sitä mainiosti tukevat valokuvat. Ylipäänsä, läpi koko kirjan, valokuvat tukevat osuvasti teoksen kirjallista sisältöä.

Kirjan artikkelit on päivitetty ja osin uudelleenkirjoitettu sitten vuoden 1994 konferenssiesitysten. Maisema-käsitteen kanssa jonkin verran tuttavuutta tehneenä lukijana en voinut kuitenkaan joidenkin kirjan artikkeleiden kohdalla välttyä tuntemukselta "olen lukenut tämän jo aiemmin". Tuntemus korostui etenkin kirjan filosofispainotteisella alkupuolella. Tuttuuden tunne johtunee ainakin osin siitä, että maiseman ja estetiikan teema toistuu, joskin spesifimmin tiettyihin maisema-alueisiin ja -muotoihin sitoutuen, kirjasarjan aiemmin ilmestyneissä teoksissa. Toisaalta taas osa kirjoittajista on kirjoittanut runsaasti maisema-käsitteestä ja siihen nivoutuvista tarkasteluistaan jo muissa julkaisuissa, jolloin käsillä oleva kirja ei varsinaisesti tarjoa kovinkaan uusia näkökulmia asiaan. Siinä mielessä olisi ollut toivottavaa, että kirja olisi saatu julkaistua jo aiemmin. Mutta parempi myöhään kuin ei milloinkaan, joka tapauksessa kirjan ilmestyminen on hyvä asia ja se on tärkeä osa koko kirjasarjaa ajatellen. Maisemasta ja ympäristöestetiikasta kiinnostuneelle lukijalle teos tarjoaa hyvän pohjustuksen ja avaran tietopaketin. Tunnettujen kansainvälisten tutkijoiden suomen kielelle käännetyt tekstit ovat myös aina erityistä herkkua, jota ei kannata jättää väliin. Kokonaisvaikutelmaltaan kirja jättää jälkeensä raikkaita, mieleenpainuvia kuvia ja käsityksen maiseman laaja-alaisesta olemuksesta, niin aistittuna kuin käsitteellisesti ymmärrettynä. 


\section{KirJallisuUs}

HAKALA, KIRSI (toim.) 1999: Suo on kaunis. Helsinki: Maahenki Oy.

SEPÄNMAA, YRJÖ \& HEIKKILÄ-PALO, LIISA (toim.) 2002: Vesi vetääpuoleensa. Helsinki: Maahenki Oy.

— (toim.) 2005: Pellossa perihopeat. Helsinki: Maahenki Oy.

SEPÄNMAA, YRJÖ \& HEIKKILÄ-PALO, LIISA \& KAUKIO, VIRPI (toim.) 2003:

Metsään mieleni. Helsinki: Maahenki Oy.

Filosofian tohtori Kirsi Laurén työskentelee suunnittelijana Terveyden monikulttuuriset ulottuvuudet -hankkeessa Joensuun yliopistossa. 